\title{
PRODUKSI DAN PENENTUAN KONDISI OPTIMUM ENZIM XILANASE Bacillus amyloliquefaciens FUKUMOTO PADA SUBSTRAT XILAN JERAMI
}

\author{
Widiyanti Sekatresna ${ }^{1,2}$, Abdi Dharma ${ }^{2}$ Periadnadi $^{3}$ \\ ${ }^{1}$ SMA N 2 Lubuk Basung \\ ${ }^{2}$ Program Studi Kimia Pasca Sarjana Universitas Andalas \\ ${ }^{3}$ Jurusan Biologi FMIPA Universitas Andalas Padang
}

\begin{abstract}
The production and determination of optimal condition of xylanase produced by Bacillus amyloliquefaciens on rice straw xylan were investigated in this study. The parameters to be observed were optimal conditions of $\mathrm{pH}$, temperature, substrate concentration and incubation time. Xilanase activity was determined by measuring the amount of reducing sugar formed in the enzymatic reaction based on Somogyi Nelson method. Optimal conditions needed for the production of xylanase were at $\mathrm{pH} 7$, temperature $27^{\circ} \mathrm{C}$ and six days of incubation time. While optimal conditions of xylanase action were reached at $\mathrm{pH} 8.2$, temperature $45^{\circ} \mathrm{C}$, substrate concentration $3.5 \%(\mathrm{w} / \mathrm{w})$ and 15 minutes of incubation time with enzyme activity and enzyme specific activity of $1.285 \mathrm{U} / \mathrm{mL}$ and $0.738 \mathrm{U} / \mathrm{mg}$ respectively. As a comparison, xylanase was also produced on pure xylan (birchwood), enzyme activity and enzyme specific activity obtained were $2.701 \mathrm{U} / \mathrm{mL}$ and $1.658 \mathrm{U} / \mathrm{mg}$ respectively. Cellulase content in enzyme produced on rice straw xilan showed the enzyme activity of $0.094 \mathrm{U} / \mathrm{mL}$.
\end{abstract}

Keywords : xylanase, Bacillus amyloliquefaciens, rice straw xilan

\section{DAFTAR PUSTAKA}

1. N. Richana, Produksi dan Prospek Xilanase dalam Pengembangan Bioindustri di Indonesia, Buletin Agrobio, 5(1): 29 36, (2002),

2. I. Seyis, and N. Aksoz, Xylanase Production from Trichoderma harzianum 1073 D3 with Alternative Carbon and Nitrogen Sources, Food Technology and Biotechnology, 43(1): 37 -40, (2005).

3. S. Weber, S. Stubner, and R. Conrad, Bacterial Population Colonizing and Degrading Rice Straw in Anoxic Paddy Soil, Applied and Environmental Microbiology, 67(3): 1318 - 1327, (2000).

4. Trismillah, W. Deden dan Sumaryanto, Produksi Xilanase, Pengaruh Komposisi Media pada Produksi Xilan, Bacillus stearothermophillus DSM 22 Menggunakan Substrat Kulit Buah Pisang, Pustaka IPTEK J. Sains dan Teknologi BPPT, VII.IIA.01, (2005).
5. D. S. Reis, F. A. M. Costa and M. R. Peralta, Xylanase Production by A wild Strain of Aspergillus Nidulans, Acta Scientiarum Biological Science, Brazil, (2003).

6. R. W. Kenealy, and W. T. Jeffries, Enzym Processes for Pulp and Paper: A Review of Recent Developments, Institute for Microbial and Biochemical Technology, U.S. Madison, $210: 215$, (2003)

7. P. Wahyudi, Enzim Xilanase, Teknologi Bersih untuk Bleaching Pulp, Harian Sinar Harapan, No.4053, (2002).

8. J. G. Tortora, R. B. Funke and L. C. Case, Microbiology An Introduction, Eighth Edition. Pearson Education, Benjamin Cummings, San Franscisco, 2004, 112 118.

9. M. Hein, R. L. Best, S. Patisson, and S. Arena, Introduction to Organik and Biochemistry. Brooks/Cole Publishing Company, California, 2000, $324-3357$. 
